\title{
Seasonal impact of the microzooplankton on pico- and nanoplankton growth rates in the northwest Mediterranean Sea
}

\author{
Christine Ferrier-Pagès, Fereidoun Rassoulzadegan
}

URA-CNRS 716, Station Zoologique, BP 28, F-06230 Villefranche-sur-Mer, France

\begin{abstract}
The effect of protozoan presence on pico- and nanoplankton growth rates was studied during a whole seasonal cycle, together with several other environmental factors (such as microphytoplankton abundance, temperature, salinity, solar irradiance and nutrients). Pico- and nanoplankton growth rates were enhanced in the presence of protozoa inside a dialysis bag and reached values as high as 0.08 to $0.2 \mathrm{~h}^{-1}$ At in situ concentrations $\left(10^{6}\right.$ flagellates $\mathrm{l}^{-1}$ and $10^{3}$ ciliates $\left.\mathrm{l}^{-1}\right)$, protozoa, through their excretory activity, played an important role in phytoplankton growth. However, other environmental factors, such as allochthonous nutrients and temperature, also have an effect on these growth rates.
\end{abstract}

KEY WORDS: Microzooplankton - Pico- and nanoplankton growth - Seasonal cycle Regenerated production

\section{INTRODUCTION}

Pico- and nanoplankton abundance and growth are under the control of a variety of factors, such as sedimentation, predation, temperature, light, nutrient availability or phytoplankton abundance (Crisman et al. 1984, Harris 1986, Moll \& Brahce 1986, Sommer et al. 1986). Thus, several biotic and abiotic factors can interact to change pico- and nanoplankton standing stocks. In the euphotic zone of oligotrophic oceans, one of the most important factors for primary producers is nutrient availability. Nutrients are often recycled in situ by zooplankton excretion. Protozoa are probably the major group of organisms responsible for nutrient recycling (Glibert 1982, Caron \& Goldman 1990, Ferrier \& Rassoulzadegan 1994). This protozoan activity has a direct effect on autotrophic pico- and nanoplankton growth rates (Ferrier \& Rassoulzadegan 1991). In this work, we studied, during a whole seasonal cycle, (1) the relationship between some physico-chemical factors and pico- and nanoplankton occurrence in the surface oligotrophic waters of the northwest Mediterranean Sea and (2) the seasonal effect of protozoan occurrence on picoplankton growth rates.

\section{MATERIAL AND METHODS}

Experimental design. Surface seawater was taken every week during 1990 and 1991 at Point B (43 41' $\left.10^{\prime \prime} \mathrm{N}, 7^{\circ} 19^{\prime} 0^{\prime \prime} \mathrm{E}\right)$, a standard oceanographic station outside the Bay of Villefranche-sur-Mer. Seawater was first screened through a $100 \mu \mathrm{m}$ size mesh, using a reverse filtration device (Sheldon \& Rassoulzadegan 1987 ), to remove mesozooplankton. Five liters of this filtrate was subsequently fractionated in $<2 \mu \mathrm{m}$ and $>2 \mu \mathrm{m}$ using the above filtration device and a $2 \mu \mathrm{m}$ Nuclepore membrane. The $<2 \mu \mathrm{m}$ fraction was poured into a 61 Pyrex bottle. This fraction contained mostly picoplankton (heterotrophic bacteria, cyanobacteria and auto- and heterotrophic picoflagellates). The $>2 \mu \mathrm{m}$ fraction was condensed over the filter into $1 \mathrm{l}$ and poured into a dialysis bag, previously boiled and rinsed several times in distilled water (Fig. 1). This fraction contained few picoplankton remaining in suspension in the water and mostly nano- and microplankton. The dialysis bag was then closed by a knot, immersed in the bottle containing the $<2 \mu$ m fraction and the system was incubated in running seawater, under in situ light and seawater temperature for $12 \mathrm{~h}$. 


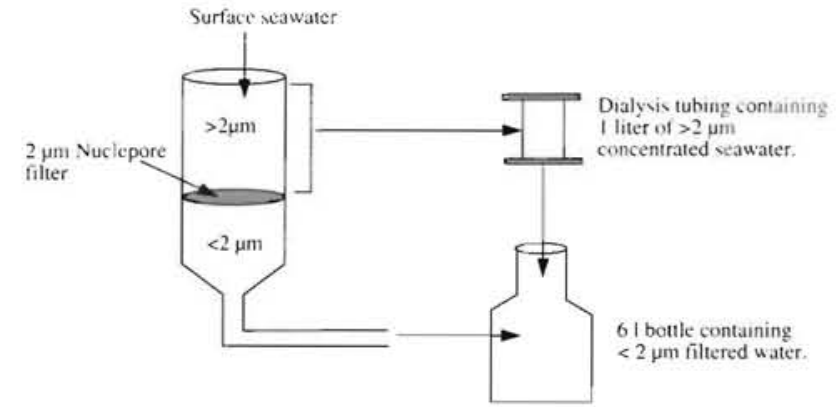

Fig. 1 View of the experimental system

A control bottle, with the same $<2 \mu \mathrm{m}$ fraction as the experimental bottle and a dialysis bag containing $0.22 \mu \mathrm{m}$ Sterivex Millipore-filtered seawater, was also prepared and incubated under the same conditions. Different physico-chemical factors were measured in both experimental and control bottles during the incubation time: seawater temperature, salinity, density, nutrients and solar irradiance.

Triplicate samples were taken for cell enumeration: (1) immediately after sampling for measuring plankton abundance during the whole year, and ( 2 ) in the $<2 \mu \mathrm{m}$ and $>2 \mu \mathrm{m}$ fractions at the beginning and at the end of the incubation time, in both control and experimental bottles. Samples for pico- and nanoplankton enumeration were fixed with $3 \%$ formaldehyde, stained with DAPI according to Porter \& Feig (1980) and observed with a Zeiss Axiophot epifluorescence microscope. Samples for microplankton enumeration were fixed with Lugol and observed with an inverted Zeiss microscope (Utermöhl 1958). Nutrient concentrations (nitrate, nitrite, phosphate and silicate) were measured with a Technicon Autoanalyser II according to Treguer \& Le Corre (1975). Solar irradiance, temperature, salinity and density were provided by standard hydrological survey at Point B (M. Etienne pers. comm.). In these experiments, seasonal variations of the different groups studied are given in cells $\mathrm{I}^{-1}$ and in $\mathrm{ppm} / \mathrm{v}$ $\left(\mathrm{ppm} / \mathrm{v}=\right.$ number of cells $\mathrm{ml}^{-1} \times$ cell volume $\left.\times 10^{-6}\right)$. Conversion factors for transforming cell enumeration to biomass are given in Lins da Silva (1991). These cell volumes were originally obtained after several cell size measurements were performed in the Bay of Villefranche-sur-Mer.

Picoplankton growth rates, $\mu\left(\mathrm{h}^{-1}\right)$, in the experimental and control bottles were calculated as following :

$$
\mu=\left(\ln C_{2}-\ln C_{1}\right) / T
$$

where $C_{1}$ and $C_{2}$ are the cell concentrations (cells $\mathrm{ml}^{-1}$ ) at the beginning and the end of the incubation time, $T(\mathrm{~h})$.
Statistical treatments. Effect of selected physicochemical factors on pico- and nanoplankton abundance: In order to examine relationships between physico-chemical factors and pico- and nanoplankton abundance, we performed a correspondence analysis which is an ordination method widely used in analysis of ecological data (Gower 1987). This analysis was computed with the physico-chemical and biological factors as variables and weekly measurements as observations.

The physico-chemical factors considered were: seawater temperature, density, salinity, nutrients (nitrate, nitrite, silicate and phosphate) and solar irradiance.

Biological factors taken into account were: abundance of cyanobacteria, auto- and heterotrophic picoand nanoflagellates and heterotrophic bacteria.

Effect of environmental factors on picoplankton growth rates: We examined growth rates of the different groups of picoplankton (cyanobacteria, bacteria, Prochlorococcus, auto- and heterotrophic flagellates) and compared the rates obtained in control and experimental bottles. Picoplankton growth rates were therefore determined from a variance analysis for each experiment and each bottle (with normalized data). Concentrations of the different groups studied were compared for each experiment, before and after $12 \mathrm{~h}$ incubation time, and the following hypotheses were tested: (1) no growth in the control bottle; (2) no growth in the experimental bottle; and (3) no difference in growth between the experimental and control bottles. Whenever a significant growth was observed, specific growth rates were calculated, otherwise we assumed that growth rates were null. The difference between growth rates in the experimental and control bottles gives 'induced growth rates' (due to presence of a dialysis bag containing naturally occurring protozoa).

A multiple regression was subsequently computed between induced growth rates calculated for the different groups and during the whole year and the environmental factors studied: seawater temperature, salinity, density, nutrients (nitrate, nitrite, silicate and phosphate), and biomass inside the dialysis bag (i.e. biomass of ciliates, heterotrophic pico- and nanoflagellates and microphytoplankton). Solar irradiance was the only factor highly correlated ( $1 \%$ level) with some of the other factors cited above and was discarded.

\section{RESULTS}

\section{Seasonal cycles of physical factors}

Results of physico-chemical tests are shown in Fig. 2. Seawater temperature was stable from October to April $\left(13^{\circ} \mathrm{C}\right)$, increased regularly until July $\left(28^{\circ} \mathrm{C}\right)$ and 

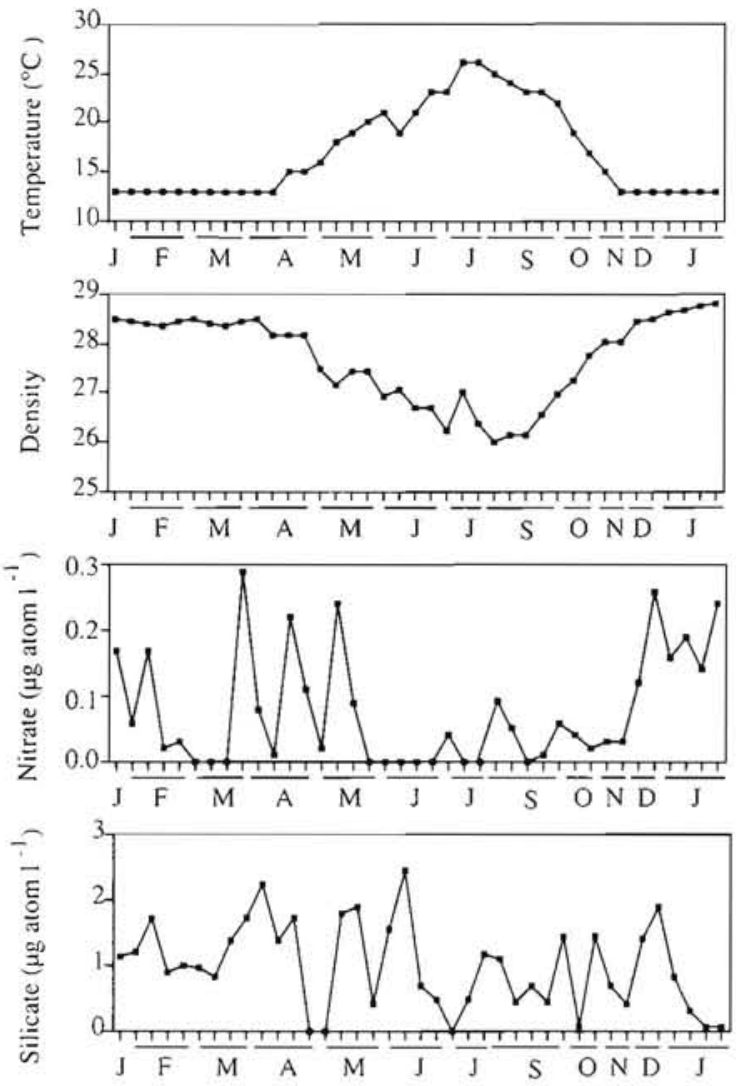

Time (months)
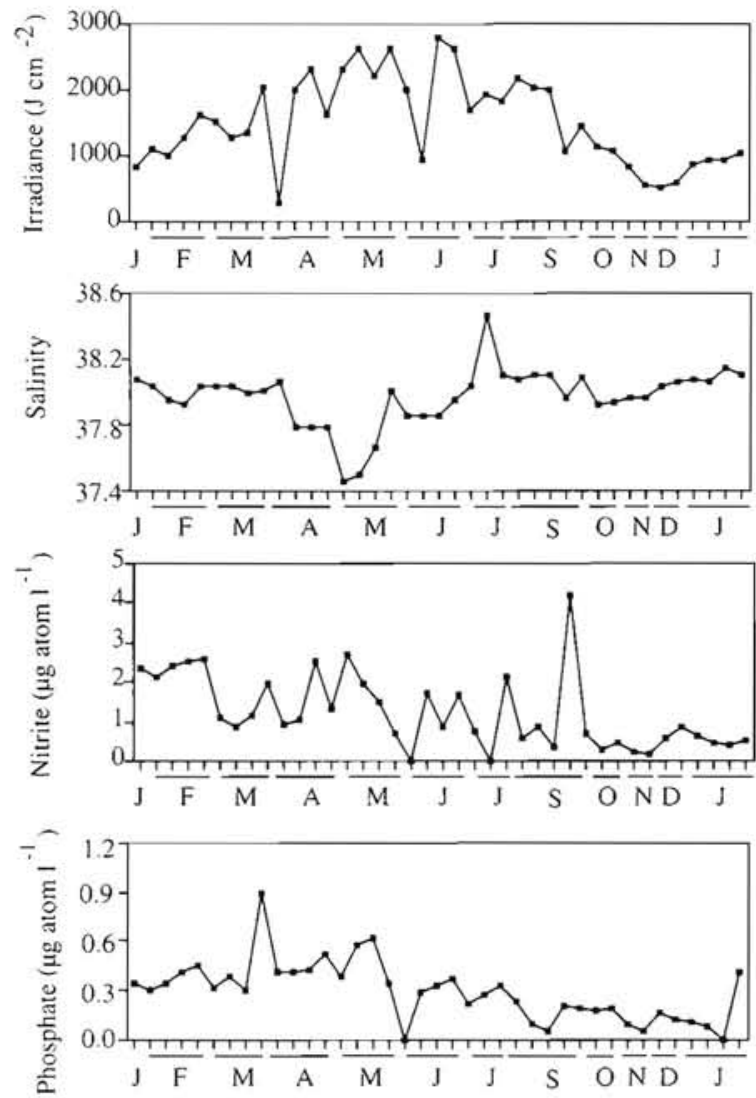

Time (months)

Fig. 2. Seasonal variations of the physico-chemical factors studied outside the Bay of Villefranche-sur-Mer, France

decreased thereafter. Natural irradiance followed the same pathway and varied from 0.5 to $3 \times 10^{3} \mathrm{~J} \mathrm{~cm}^{-2}$. The density curve was inverse when compared to the temperature, with the highest and lowest values equal to 28.5 and 26.5 respectively. Salinity was relatively stable during the whole year $(38 \%)$ except during May $(37.5 \%$ ). As far as nutrients are concerned, nitrate concentrations varied between 0 and $0.3 \mu \mathrm{M}$ and presented several peaks between March and May, and in December and January. Nitrite and silicate concentrations were highly variable ( 0 to $3 \mu \mathrm{M})$ and phosphate concentrations remained low during the whole year ( 0 to $0.3 \mu \mathrm{M})$.

\section{Seasonal variations of biomass}

Cyanobacteria presented 2 maxima (Fig. 3), in March and from July to the beginning of September ( 7 to $13 \times$ $10^{7}$ cells $\mathrm{l}^{-1}$ or 0.012 to $0.025 \mathrm{ppm} / \mathrm{v}$ ). Concentrations were lower during the rest of the year $\left(2.5\right.$ to $5 \times 10^{6}$ cells $1^{-1}$ or 0.005 to $0.01 \mathrm{ppm} / \mathrm{v}$ ).

Autotrophic picoflagellate abundance varied from 0.5 to $5.2 \times 10^{6}$ cells $1^{-1}$, with very low values in
March. Heterotrophic picoflagellate biomass varied from 0.6 to $4.8 \times 10^{6}$ cells $\mathrm{I}^{-1}(0.001$ to $0.006 \mathrm{ppm} / \mathrm{v})$. Autotrophic nanoflagellates presented important changes in biomass, with several peaks in the middle of February and March $\left(0.07 \mathrm{ppm} / \mathrm{v}, 1 \times 10^{6}\right.$ cells $\left.\mathrm{l}^{-1}\right)$, at the end of April $\left(0.06 \mathrm{ppm} / \mathrm{v}, 9 \times 10^{5}\right.$ cells $\left.\mathrm{l}^{-1}\right)$, and at the beginning of July $\left(0.08 \mathrm{ppm} / \mathrm{v}, 1.22 \times 10^{6}\right.$ cells $\mathrm{1}^{-1}$ ). During the rest of the year, biomass ranged from 0.02 to $0.03 \mathrm{ppm} / \mathrm{v}$ ( 3 to $4 \times 10^{5}$ cells $\mathrm{I}^{-1}$ ). Heterotrophic flagellates had higher biomass during the winter months $\left(0.02\right.$ to $0.04 \mathrm{ppm} / \mathrm{v}$ or 4 to $8 \times 10^{5}$ cells $\left.1^{-1}\right)$ than the rest of the year $(0.01 \mathrm{ppm} / \mathrm{v}$ or 1.5 to $2 \times$ $10^{5}$ cells $\mathrm{l}^{-1}$ ).

Bacterial biomass varied during the year from 3 to 7 $\times 10^{8}$ cells $\mathrm{l}^{-1}(0.015$ to $0.03 \mathrm{ppm} / \mathrm{v})$, except for a small decrease from November to January $\left(1.5 \times 10^{8}\right.$ cells $l^{-1}$, $0.01 \mathrm{ppm} / \mathrm{v}$ ). Some succession patterns were observed between heterotrophic bacteria, pico- and nanoflagellates (Fig. 4), each peak of bacteria being followed after $1 \mathrm{wk}$ by a peak of picoflagellates, immediately followed by a peak of nanoflagellates. Results from a Spearman correlation analysis between abundance of bacteria and picoflagellates and between pico- and 


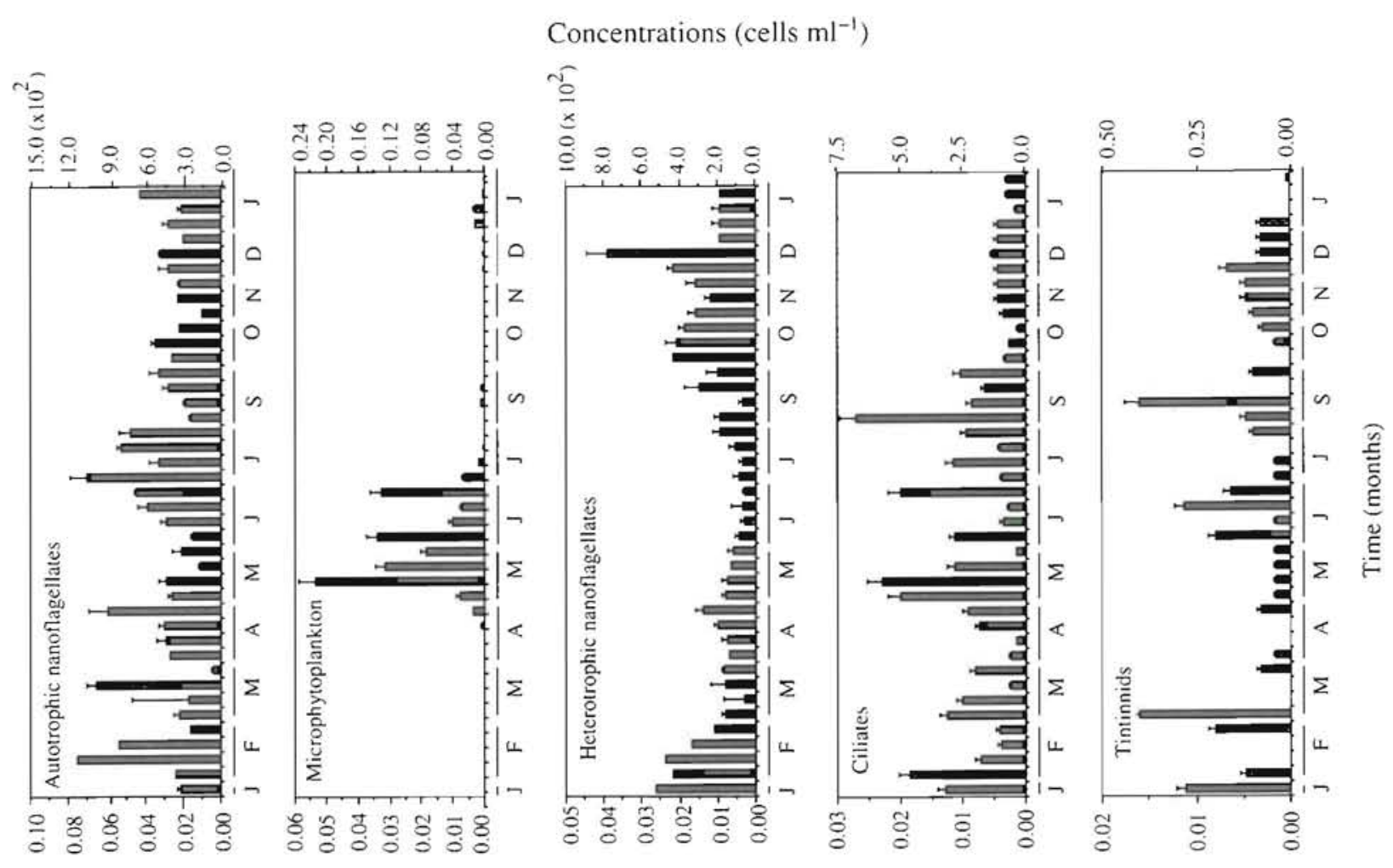

Biomass (ppm/v)

Concentrations (cells $\mathrm{ml}^{-1}$ )
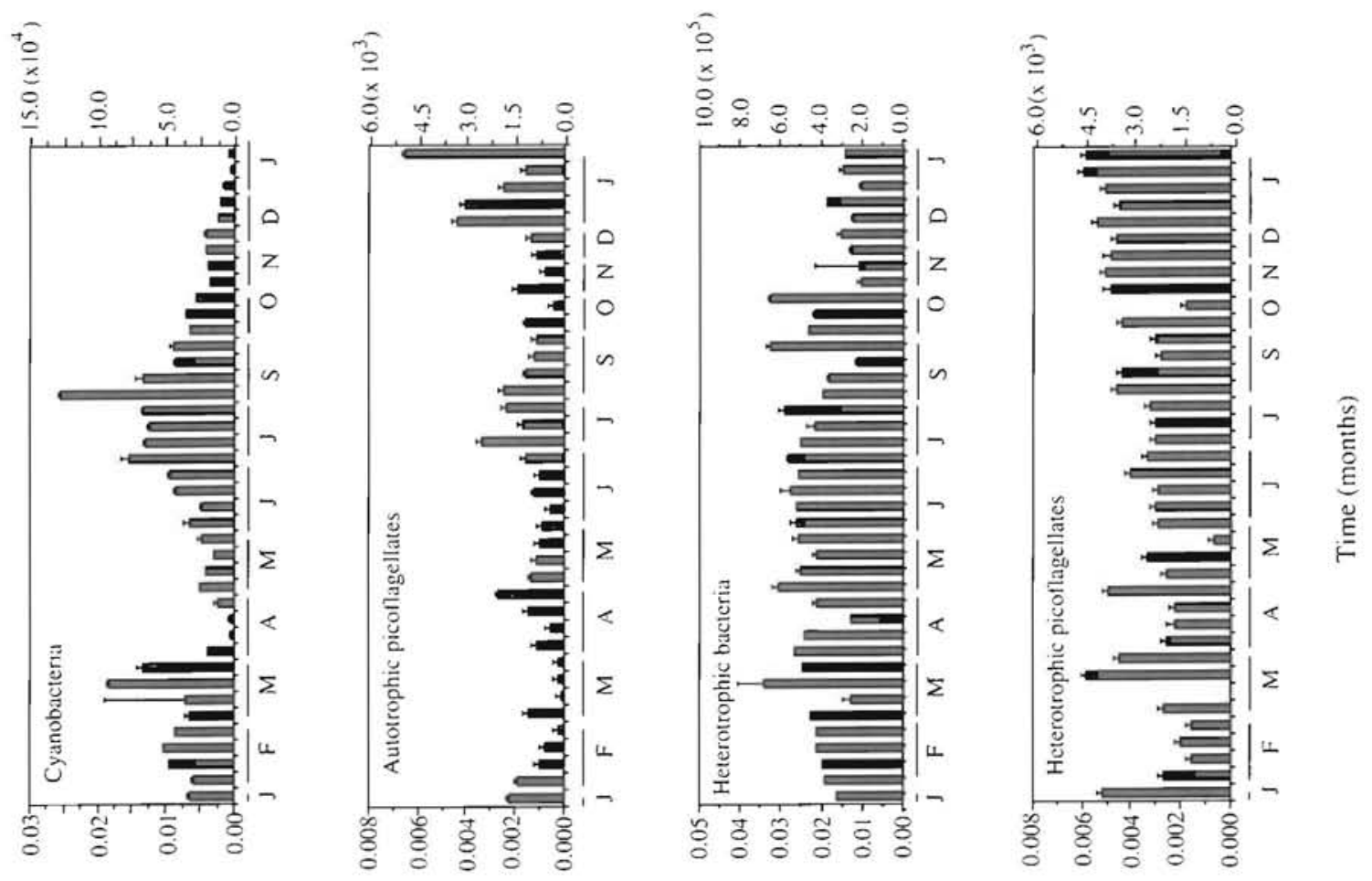

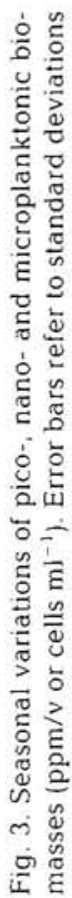

Biomass (ppm/v) 
nanoflagellates show significant inverse correlations at the $5 \%$ level (Spearman coefficients equal to 0.647 and 0.506 for 39 data respectively).

Microphytoplankton biomass remained low during the whole year, except for the spring bloom period which occurred between May and June 10.04 to 0.06 $\mathrm{ppm} / \mathrm{v}$ ). Diatoms (Chaetoceros sp., Rhizosolenia styliformis and $R$. stolterföthii, Nitzschia sp., Leptocylindrus sp.) and dinoflagellates (Gymnodinium sp. and Gyrodinium sp.) were the main species.

Ciliates were also abundant during the whole year ( 1 to $2 \times 10^{3}$ cells $1^{-1}$ ), with a maximum in May, July and September $\left(0.02\right.$ to $0.03 \mathrm{ppm} / \mathrm{v}$ or $\left.5 \times 10^{3} \mathrm{l}^{-1}\right)$. Oligotrichous ciliates (mainly Strombidium sp.) were the most abundant, followed by tintinnids.

\section{Effect of selected physico-chemical factors on pico- and nanoplankton abundance (correspondence analysis)}

According to the cluster analysis, 7 groups can be distinguished (Fig. 5), giving the following correlations: (I) cyanobacteria, nitrite, phosphate and spring months (March and April); (II) heterotrophic flagellates and winter months (December); (III) nitrate and winter months (January and February); (IV) seawater temperature and summer months (July and September); (V) heterotrophic bacteria, irradiance and summer months (June); (VI) autrophic flagellates, salinity and October; (VII) silicate and the month of May.

Projections of the data in the 1-2 factorial plane are shown in Fig. 6 and Table 1. This plane represented $35 \%$ of the inertia of the cloud. Axis 3 is not taken into account because
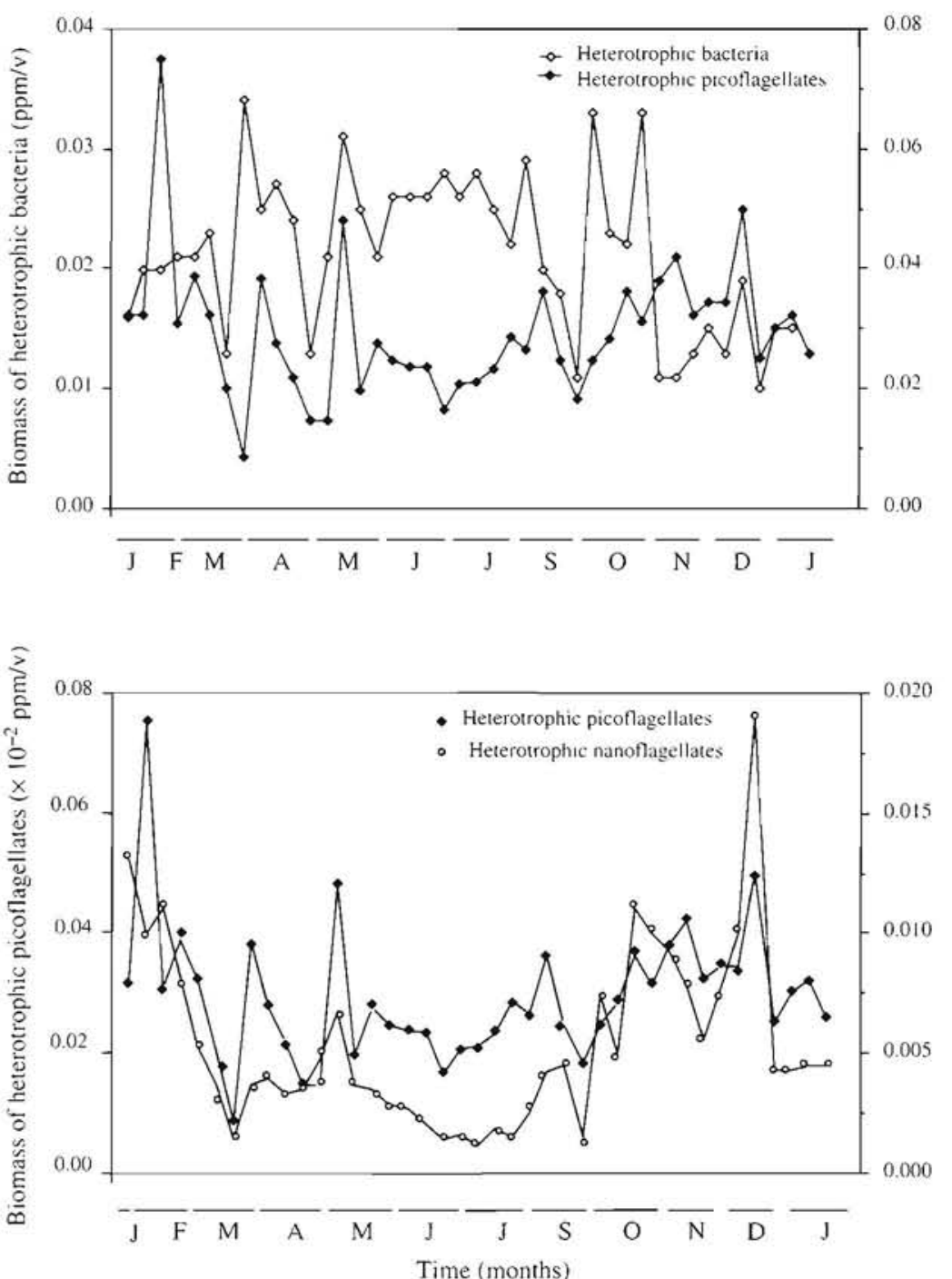

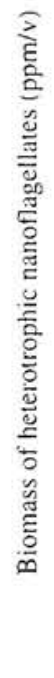

Fig. 4. Relations between the occurrence of heterotrophic bacteria, pico- and nanoflagellates it represented only $13 \%$ of the inertia of the cloud and variables had low contributions $(<15 \%)$ to this axis. Seawater temperature and density had the highest contributions to axis $1(84.68$ and $76.80 \%$ respectively), while phosphate and nitrite had high contributions to axis 2 (63.19 and $32 \%$ respectively). Therefore, axes 1 and 2 should be a temperature and a nutrient gradient respectively. Negative values on axes 1 and 2 correspond to high temperatures and phosphate concentrations respectively. As far as axis 1 is concerned, phosphate, nitrite and autotrophic flagellates are near to zero and are therefore independent relative to seawater temperatures (Fig. 6). Cyanobacteria, heterotrophic flagellates, silicate and nitrate are in opposition with temperature, irradiance and heterotrophic bacteria. Cyanobacterial occurrence depended much more on nutrient abundance than on high values of temperature and irradiance. On the other hand, heterotrophic bacteria are highly correlated with high seawater temperatures. As far as axis 2 is concerned, heterotrophic bacteria, near to zero, are independent relative to phosphate concentrations. Auto- and heterotrophic flagellates are in opposition, on axis 2, with nutrients and cyanobacteria. 


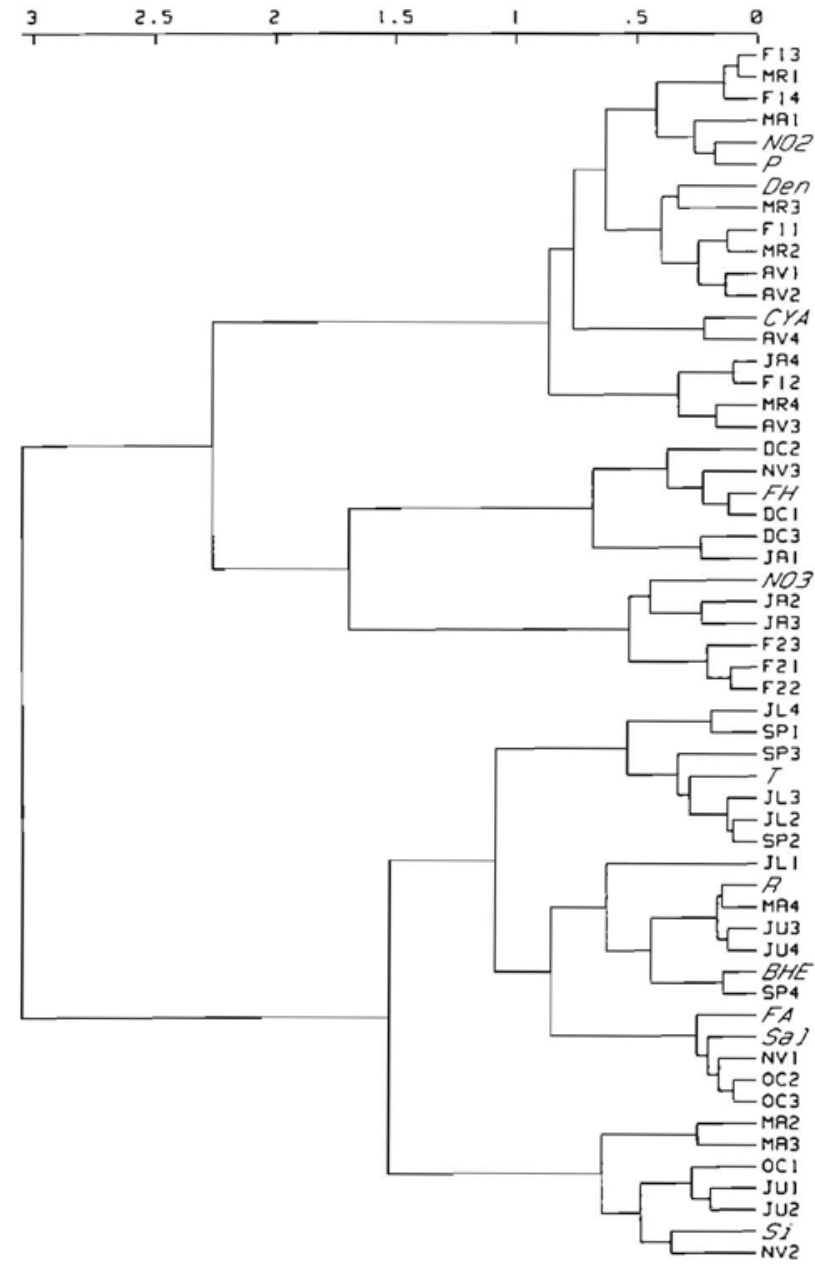

Fig. 5. View of the cluster analysis. JA: January; F: February; MR: March; AV: April; MA: May; JU: June; JL: July; SP: September; OC: October; NV: November; DC: December. Number following month indicates week number except in February where number refers to actual date. CYA: cyanobacteria; FA: autotrophic flagellates; $F H$ : heterotrophic flagellates; $B H E$ : heterotrophic bacteria; Den: density; $T$ temperature; Sal: salinity; $P$ : phosphate; NO2: nitrite; NO3: nitrate; SI: silicate; $R$ : radiance

\section{Effects of environmental factors on picoplankton growth rates}

The variance analysis indicated that growth rates were higher in experimental than in control bottles (Fig. 7). In the experimental bottle, they varied from 0 to $0.2 \mathrm{~h}^{-1}$ for Prochlorococcus spp., 0 to $0.08 \mathrm{~h}^{-1}$ for cyanobacteria and heterotrophic bacteria, 0 to $0.19 \mathrm{~h}^{-1}$ for autotrophic picoflagellates, 0 to $0.16 \mathrm{~h}^{-1}$ for heterotrophic picoflagellates. Some autotrophic nanoflagellates, which passed through the $2 \mu \mathrm{m}$ filter, also had their growth enhanced with a dialysis bag (Fig. 8). Growth rates reached values as high as $0.13 \mathrm{~h}^{-1}$.

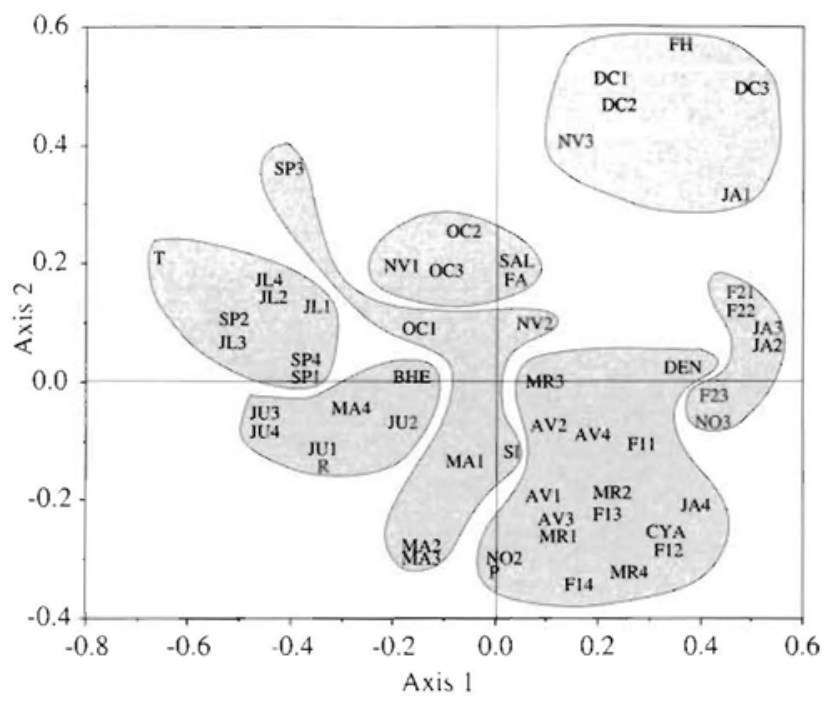

Fig. 6. View of the 1-2 plane of the correspondence analysis. Abbreviations as in Fig. 5

\section{Relation between environmental factors and growth rates}

Results from the multiple regression analysis are given in Table 2. The abundance of ciliates and heterotrophic pico- and nanoflagellates (in the dialysis bag) was the most important factor explaining cyanobacterial and also autotrophic pico- and nanoflagellates growth rates. However, phosphate and seawater salinity also had a high correlation with the growth of autotrophic pico- and nanoflagellates respectively. Prochlorococcus spp. growth was correlated to abiotic factors such as seawater temperature, phosphate and nitrite, but also to the heterotrophic

Table 1. Contributions of variables to the different axes (\%)

\begin{tabular}{|lrrrr|}
\hline Variables & Axis 1 & Axis 2 & Axis 3 & Axis 4 \\
\hline Temperature & 84.68 & 7.45 & 2.89 & 0.30 \\
Irradiance & 55.93 & 10.34 & 0.57 & 0.50 \\
Nitrate & 26.01 & 1.05 & 54.04 & 13.54 \\
Nitrite & 0.35 & 32.09 & 8.94 & 3.86 \\
Phosphate & 0.71 & 63.19 & 0.59 & 0.05 \\
Silicate & 1.29 & 5.91 & 22.98 & 54.35 \\
Salinity & 0.03 & 36.48 & 0.02 & 1.76 \\
Density & 76.80 & 0.03 & 3.27 & 0.71 \\
Cyanobacteria & 21.12 & 17.83 & 22.20 & 12.99 \\
Heterotrophic & 23.89 & 0.00 & 31.32 & 1.38 \\
$\quad$ bacteria & & & & \\
Autotrophic & 0.31 & 17.84 & 5.38 & 26.07 \\
$\quad$ flagellates & & & & \\
Heterotrophic & 20.11 & 62.23 & 1.15 & 4.55 \\
flagellates & & & & \\
\hline
\end{tabular}



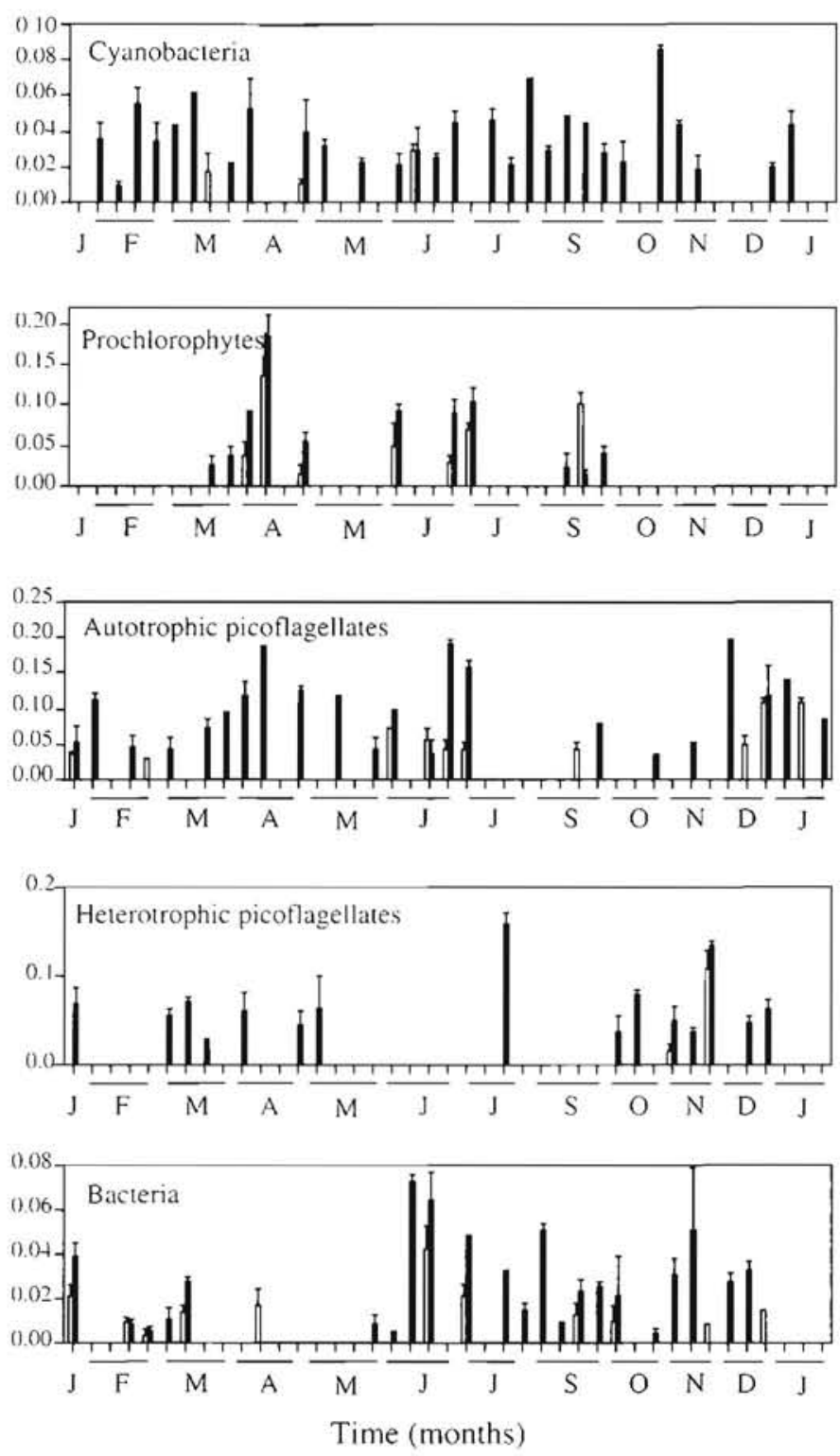

Fig. 7 Seasonal variations of picoplankton growth rates $\left(\mathrm{h}^{-1}\right)$, in the experimental (solid bars) and control (open bars) bottles

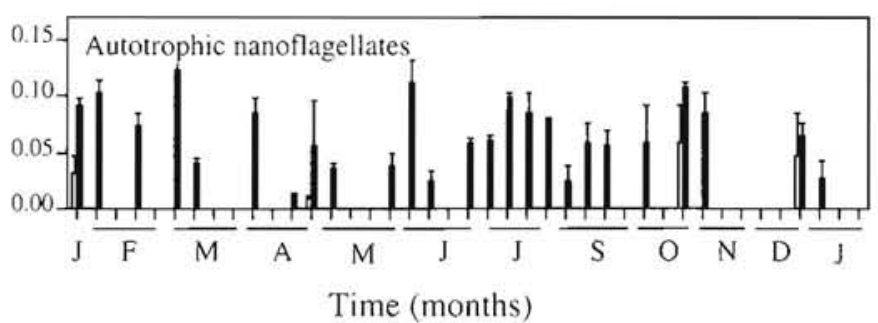

Fig. 8. Seasonal variations of nanoplankton growth rates $\left(\mathrm{h}^{-1}\right)$, in the experimental (solid bars) and control (open bars) bottles picoflagellates abundance in the dialysis bag. There was no relation between the environmental factors and heterotrophic bacteria. Moreover, for each group, growth rates were classed in intervals of 0.01 units. Average values were calculated for each interval of growth rate and for corresponding selected factors. Average growth rates were then plotted against average values of selected factors (Fig. 9). Autotrophic picoflagellate growth rates were linked to the abundance of ciliates, heterotrophic flagellates and phosphate. Prochlorococcus spp. growth rates were under the influence of temperature and heterotrophic picoflagellates. Positive relations were also obtained between the abundance of ciliates and growth rates of cyanobacteria and nanoflagellates.

\section{DISCUSSION}

The Bay of Villefranche-sur-Mer is considered a temperate coastal system. Productivity is highly seasonal, with production highest in spring. In contrast to other temperate waters, where blooms of diatoms are responsible for most of the primary production (Takahashi \& Bienfang 1983. Joint et al. 1986), pico- and nanoplankton are the major groups in the waters studied, even during the spring months (Rassoulzadegan 1979, Selmer et al. 1993). This work is one of the first reports on seasonal pico- and nanoplankton abundance in the surface waters of the Mediterranean Sea. Moreover, this biological cycle has been linked to the cycles of some main physicochemical factors. Prochlorococcus spp. abundance may be underestimated due to the low fluorescence intensity of cells (D. Vaulot pers. comm.), and average cell fluorescence could vary seasonally. This is the reason why we have not presented the seasonal cycle of Prochlorococcus spp. in this paper. However, this should not affect the interpretation of growth rate experiments; in order to calculate Prochlorococcus spp. growth rates, we used an incubation time which we assume to be short enough (less than $1 \mathrm{~d}$ ) not to affect cell fluorescence. Therefore, the difference in cell abundance observed before and after incubation should be due to an increase in the cell concentrations rather than differences in cell fluorescence. 
Table 2. Results obtained from the multiple regression. Bold values are significant $(p=0.05$ )

\begin{tabular}{|c|c|c|c|c|c|c|}
\hline \multirow{2}{*}{$\begin{array}{l}\text { Independent factors } \\
\text { (groups inside the } \\
\text { dialysis bag) }\end{array}$} & \multicolumn{6}{|c|}{ Dependent factors (groups outside the dialysis bag). Partial $F$ values } \\
\hline & $\begin{array}{l}\text { Cyano- } \\
\text { bacteria }\end{array}$ & $\begin{array}{l}\text { Prochloro- } \\
\text { coccus spp. }\end{array}$ & $\begin{array}{l}\text { Autotrophic } \\
\text { picoflagel. }\end{array}$ & $\begin{array}{l}\text { Autotrophic } \\
\text { nanoflagel. }\end{array}$ & $\begin{array}{l}\text { Heterotrophic } \\
\text { picoflagel. }\end{array}$ & $\begin{array}{l}\text { Heterotrophic } \\
\text { bacteria }\end{array}$ \\
\hline Total ciliates & 8.332 & 1.407 & 3.681 & 3.118 & 0.691 & 0.001 \\
\hline Heterotrophic picoflagellates & 4.749 & 5.655 & 7.081 & 0.017 & 3.165 & 0.212 \\
\hline Heterotrophic nanoflagellates & 5.400 & 2.616 & 1.599 & 0.590 & 0.151 & 0.226 \\
\hline Microphytoplankton & 4.140 & 3.439 & 1.513 & 0.559 & 2.500 & 0.045 \\
\hline Nitrate & 0.483 & 0.412 & 0.563 & 0.004 & 0.895 & 0.268 \\
\hline Nitrite & 0.082 & 12.738 & 0.398 & 0.143 & 0.048 & 0.467 \\
\hline Phosphate & 0.055 & 15.411 & 3.221 & 2.020 & 0.531 & 0.965 \\
\hline Silicate & 0.321 & 0.001 & 1.027 & 1.370 & 0.087 & 1.578 \\
\hline Temperature & 0.001 & 14.697 & 0.06 & 0.142 & 0.827 & 0.744 \\
\hline Salinity & 0.028 & 0.007 & 0.005 & 2.967 & 0.120 & 1.488 \\
\hline
\end{tabular}

Results obtained from the statistical analysis showed that pico- and nanoplankton occurrence and growth rates were under 2 different controls: (1) a long-term physico-chemical control (e.g. light and
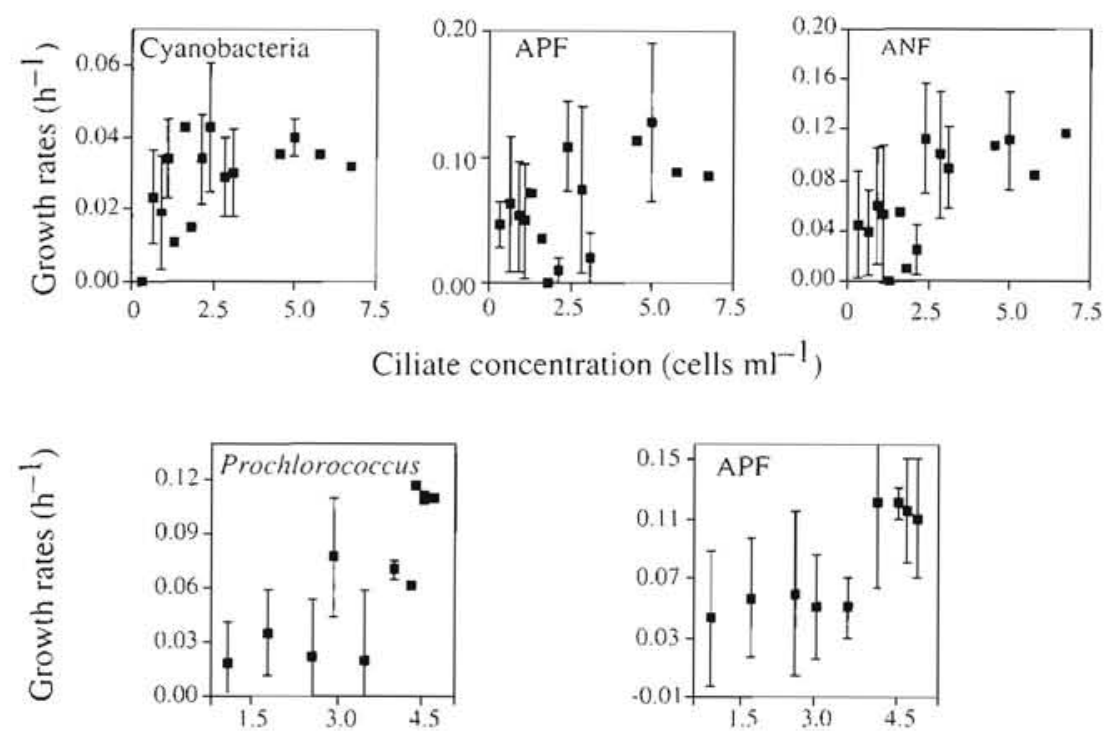

Concentration of heterotrophic picoflagellate $\left(\times 10^{3}\right.$ cells $\left.\mathrm{ml}^{-1}\right)$
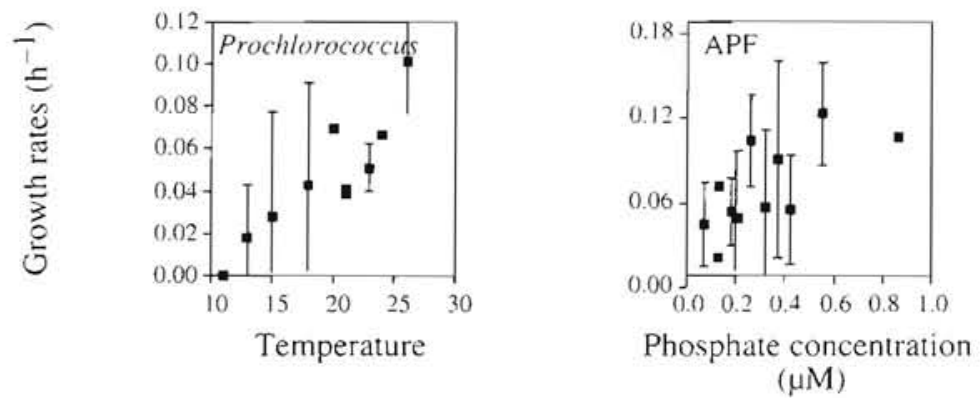

Fig. 9. Relations between selected factors and pico- and nanoplankton growth rates. Average growth rates are plotted against average concentrations of selected factors. APF, ANF; autotrophic pico- and nanoflagellates temperature) which affects growth seasonally; and (2) a short-term biological control (represented by protozoan abundance inside dialysis bags), which affects growth continuously.

As far as the biological control is concerned, this work highlights the direct effect of protozoan (mainly ciliates, heterotrophic pico- and nanoflagellates) presence and thus excretion on bacterial and phytoplankton growth (Table 2), since picoplankton growth rates (and also autotrophic nanoflagellates growth rates) were usually higher in the presence of a dialysis bag (with protozoa inside) than in the control bottle. Numerous works, based on chemical analysis or in nutrient flux in mesocosms, have shown the importance of protozoa in nutrient recycling (Glibert et al. 1988, Selmer et al. 1993, Ferrier \& Rassoulzadegan 1994). Algal utilization of nutrients released by bacterial grazing has been demonstrated in a few works (Caron et al. 1988, Ferrier \& Rassoulzadegan 1991, Rothhaupt 1992). However, this work is the first which attempted to seasonally estimate the direct effect of the presence of natural communities of protozoa on the growth rates of naturally occurring picoplanktonic communities. It was possible, by using dialysis bags, to separate predators (mainly protozoa) from their prey (picoplankton) and to allow nutrient diffusion. Dialysis bags have already been used to study phytoplankton growth (Jensen et al. 1972, Landry et al. 1984, Furnas 
1990). In a previous study, we demonstrated that, when grazing is avoided, protozoa promoted autotrophic pico- and nanoplankton growth (Ferrier \& Rassoulzadegan 1991). Using protozoan cultures. we showed that phytoplankton growth rates can reach unusually high values in the presence of a concentration of ca $10^{4}$ ciliates $1^{-1}$ or $2 \times 10^{6}$ heterotrophic flagellates $1^{-1}$ In contrast to the above study, we used natural populations at in situ concentrations in order to examine the effect of protozoan activity on pico- and nanoplankton growth. This new study shows that the influence of protozoan presence (via dialysis) on autotrophic growth can be detected even when these protozoa are in low concentrations, such as those usually observed in oligotrophic waters of the Mediterranean $\left(10^{3}\right.$ ciliates $1^{-1}$ and $5 \times 10^{5}$ to $1 \times 10^{6}$ heterotrophic flagellates $\mathrm{l}^{-1}$ ). We did not observe a linear relationship between protozoan abundance and pico- and nanoplankton growth rates. However, a significant correlation (according to the results from the multiple regression) was obtained between the growth of cyanobacteria or autotrophic flagellates and protozoan abundance, when the 2 groups were separated with a dialysis membrane. Zooplankton and protozoan excretion may have several consequences: (1) to supply essential nutrients such as nitrogen and phosphorus necessary for phytoplankton, and (2) to supply small quantities of organic material (Taylor et al. 1985) which may act as agents increasing autotrophic growth (Kirk 1980).

In such an experiment, protozoan-specific excretion rates may be decreased in dialysis bags relative to the intact assemblage since the food density decreased during the incubation. Starved protozoa exhibited low excretion rates (Caron \& Goldman 1990, Ferrier \& Rassoulzadegan 1994). However, our incubation time was probably short enough to avoid this problem. Otherwise, we would have obtained an even higher protozoan effect on pico- and nanoplankton growth rates.

Growth rates measured in control bottles (without dialysis bags) were often null or negative. However, in experimental bottles, they are of the same order of magnitude or higher than those given in the literature for the different groups (Fuhrman \& Azam 1982, Fahnenstiel et al. 1986, Stoeckner \& Antia 1986, Furnas 1991). Maximal growth rates obtained in this experiment for cyanobacteria, for instance (2.77 doublings $\mathrm{d}^{-1}$ ), are equal to growth rates obtained in the laboratory under optimal conditions (Morris \& Glover 1981, Waterbury et al. 1986, Kana \& Glibert 1987) and are higher than those obtained in situ (Iturriaga \& Marra 1988) (Table 3). Maximal growth rates of autotrophic flagellates (ca 3 doublings $\mathrm{d}^{-1}$ ) are also higher in this experiment than those previously measured in laboratory or in situ conditions (Throndsen 1976, Platt et al. 1983, Takahashi \& Bienfang 1983, Glover et al. 1987. Furnas 1990) (Table 3).

If we compare the response of the different groups (in terms of growth rates) in the presence of protozoa, we have the following hierarchy for the importance of protozoan excretion: cyanobacteria > autotrophic flagellates $>$ heterotrophic bacteria $>$ Prochlorococcus spp.

Cyanobacterial growth rates were always enhanced in the presence of protozoa. Physico-chemical factors were not very important for this growth, except possibly for the following experiments, where no growth

Table 3. Growth rates measured under in situ or laboratory conditions for cyanobacteria and autotrophic flagellates

\begin{tabular}{|llc|}
\hline Source & Location & $\begin{array}{c}\text { Growth rates (doublings d } \mathrm{d}^{-1} \text { ) } \\
\text { in situ }\end{array}$ \\
in culture
\end{tabular}


was observed in the presence of protozoa: from the end of November to January, when temperature and irradiance reached their lowest values; from the end of April to the beginning of May, when salinity decreased suddenly; and the first week of July, because irradiance was very low at that time.

Autotrophic flagellates were the second group, after cyanobacteria, to be under the influence of protozoan excretion. Physico-chemical factors were important for picoflagellate growth only from July to November; during this period, nitrate concentrations were the lowest of the whole year and may have limited growth. On the other hand, during the months of March, April, May, December and January, when nitrate concentrations were high, and in the presence of protozoa, picoflagellate growth rates were also high. This resuit suggests that there should be a tight coupling between biological, physical and chemical factors, and that all these factors have to be taken into account to explain pico- and nanoplankton growth rates.

As far as bacterial growth is concerned, it was enhanced only periodically by protist presence. This may be due to the grazing pressure which can account for 30 to $120 \%$ of growth rates in these groups (Fahnenstiel et al. 1991). In situ, bacterial production seemed indeed to be balanced by heterotrophic flagellates, since a peak of flagellates was observed after each peak of bacteria. Growth rates were especially enhanced from June to September, when we measured no growth of heterotrophic flagellates.

In these oligotrophic waters, picoplankton production is simultaneously regulated through a 'loop control', i.e. protozoan grazing (top down control) and protozoan excretion (bottom up control), both in balance. Since biomass in our waters is mainly represented by pico- and nanoplanktonic populations, there should be both a high recycling efficiency and a primary production based on regenerated nutrients. In the water column, there may be patches of high concentrations of ciliates, heterotrophic flagellates and bacteria which act as a 'spinning wheel' (Goldman 1988). Bacteria, or small autotrophic cells, use nutrients excreted by protozoa and are in turn grazed by them. This direct effect of protozoan excretion on phytoplankton growth seems to occur mainly within microscale heterogeneous environments (Rassoulzadegan 1993) and this work demonstrates that picoplankton growth (both heterotrophic and autotrophic) can be effectively sustained by protozoan activity. In general, selective grazing, differential nutrient regeneration and nutrient patchiness caused by zooplankton may be important mechanisms by which zooplankton affect phytoplankton (Kilham \& Kilham 1982).

As far as the physico-chemical control (seasonal control) is concerned, results from statistical treatments showed that temperature and nutrients regulated picoand nanoplankton abundance.

Occurrence of heterotrophic bacteria was linked to an increase in seawater temperature. Conclusions concerning temperature and bacterial abundance seem therefore to still be contradictory since bacteria were directly related to summer months but not to temperature. Some investigators mentioned a correlation between bacterioplankton production or activity and temperature (Hagström \& Larsson 1984, Edwars \& Meyer 1986, Scavia \& Laird 1987) but others found no correspondence (Findlay et al. 1986, Letarte \& PinelAlloul 1991). Letarte \& Pinel-Alloul (1991) suggest that the lack of correlation may be of 2 kinds: either other variables are too important to let temperature show its influence or the correlation is indirect. Lowest values of bacterial biomass were observed in winter, when seawater temperature, but also primary productivity, was low flow input of autochthonous labile organic material).

As far as nutrients are concerned, nitrite and phosphate were associated with Prochlorococcus spp. growth and autotrophic flagellate abundance. This is in agreement with the literature (Bird \& Kalff 1984, Shortreed \& Stockner 1986, Chisholm et al. 1988, Li \& Wood 1988). Cyanobacterial development was also linked to an increase in nutrient concentrations and density. Water stratification seems to be important for an optimal cyanobacterial development, whereas vertical mixing can sometimes be responsible for the loss of 30 to $80 \%$ of the total biomass (Ray et al. 1989, Fahnenstiel et al. 1991).

In conclusion, this work allowed us to show that (1) seasonal changes in biomass are linked with important changes in abiotic components and (2) protozoan excretion could create patches of high nutrient concentrations and enhanced pico- and nanoplankton growth. Nutrients excreted by protozoa allowed the growth of heterotrophic bacteria and picoplanktonic autotrophs, which can be grazed again by protozoa.

Acknowledgements. We thank John Dolan, Michèle Etienne, as well as 3 anonymous reviewers for their constructive comments. As a part of the Ph.D. program of C.F., this research is a contribution of the 'Ecologie du microzooplancton' team. and was supported by the CNRS/INSU (URA 716) and E.E.C. MAST II program targeted on the Mediterranean (contract MAST 2-CT93-0063, Medipelagos) grants.

\section{LITERATURE CITED}

Armbrust, E. V., Bowen, J. D., Olson, R. J., Chisholm, S. W. (1989). Effect of light on the cell cycle of a marine Synechococcus strain. Appl. environ. Microbiol. 55: 425-432

Bird, D. F., Kalff, J, (1984). Empirical relationship between bacterial abundance and chlorophyll concentration in fresh and marine waters. Can. J. Fish. Aquat. Sci. 41: 1015-1023 
Carpenter, E. J., Cambell, L. (1988). Diel patterns of cell division and growth rates of Synechococcus spp. in Long Island Sound. Mar. Ecol. Prog. Ser. 47 179-184

Caron, 1). A., Goldman, J. C. (1990). Protozoan nutrient regeneration In: Capriulo, G. M. (ed.) Ecology of marine protozoa. Oxford Univ. Press, New York, p. 283-306

Caron, D. A., Goldman, J. C., Dennett, M. R. (1988). Experimental demonstration of the roles of bacteria and bactivorous protozoa in plankton nutrient cycles. Hydrobiologia 159: $27-40$

Chisholm, S. W., Olson, R. J., Zettler, E. R., Goericke, R., Waterbury, J. B., Welschmeyer, N. A. (1988). A novel freeliving prochlorophyte abundant in the oceanic euphotic zone. Nature 334: 340-343

Crisman, T., Scheuerman, P., Bienert, R., Beaver, J. R., Bays, J. S. (1984). A preliminary characterization of bacterioplankton seasonality in subtropical Florida Lakes. Int. Ver. theor. angew. Limnol. Verh. 22: 620-626

Edwards, R. T., Meyer, J. L. (1986). Production and turnover of planktonic bacteria in two Southeastern blackwater rivers. Appl. environ. Microbiol. 52: 1317-1323

Fahnenstiel, G. L., Carrick, H. J., Iturriaga, R. (1991). Physiological characteristics and food-web dynamics of Synechococcus in Lakes Huron and Michigan. Limnol. Oceanogr. 36: 219-234

Fahnenstiel, G. L., Sicko-Goad, L., Scavia, D., Stoermer, E. F. (1986). Importance of picoplankton in Lake Superior. Can. J. Fish. Aquat. Sci. 43: 235-240

Ferrier, C., Rassoulzadegan, F. (1991). Density-dependent effects of protozoans on specific growth rates in pico- and nanoplanktonic assemblages. Limnol. Oceanogr. 36: 657-669

Ferrier, C., Rassoulzadegan, F. (1994). N-remineralization in planktonic protozoa. Lımnol. Oceanogr. (in press)

Findlay, S., Meyer, J. L., Risley, R. (1986). Benthic bacterial biomass and production in two blackwater rivers. Can. J. Fish. Aquat. Sci. 43: 1271-1276

Fuhrman, J. A., Azam, F. (1982). Thymidine incorporation as a measure of heterotrophic bacterioplankton production in marine surface waters: evaluation and field results. Mar. Biol. 66: 109-120

Furnas, M. J. (1982). An evaluation of two diffusion culture techniques for estimating phytoplankton growth rates in situ. Mar. Biol. 70: 63-72

Furnas, M. J. (1990). In situ growth rates of marine phytoplankton: approaches to measurement, community and species growth rates. J. Plankton Res. 12: 1117-1151

Furnas, M. J. (1991). Net in situ growth rates of phytoplankton in an oligotrophic tropical shelf ecosystem. Limnol. Oceanogr. 36: 13-29

Gieskes, W. W. C., Kraay, G. W. (1989). Estimating the carbon specific growth rate of the major algal species groups in eastern Indonesian waters by ${ }^{14} \mathrm{C}$ labelling of taxon specific carotenoids. Deep Sea Res. 36: 1127-1139

Glibert, P. M. (1982). Regional studies of daily, seasonal, and size fractionnation variability in ammonium remineralization. Mar. Biol. 70: 209-222

Glibert, P. M., Dennett, M. R., Caron, D. A. (1988). Nitrogen uptake and $\mathrm{NH}_{4}{ }^{+}$regeneration by pelagic microplankton and marine snow from the North Atlantic. J. mar. Res. 46 $837-852$

Glover, H. E., Keller, M. C., Spinrad, R. W. (1987). The effects of light quality and intensity on photosynthesis and growth of marine eukaryotic and prokaryotic phytoplankton clones. J. exp. mar. Biol. Ecol. 105: 137-159

Goldman, J. C. (1988). Spatial and temporal discontinuities of biological processes in pelagic surface waters. In: Roth- schild, B. J. (eds.) Toward a theory on biological-physical interactions in the World Ocean. Kluwer Academic Publisher, Dordrecht, p. 273-296

Gower, J. C. (1987). Introduction to ordination techniques. In: Legendre, P., Legendre, L. (eds.) Developments in numerical ecology. NATO ASI Ser. 614: 3-64

Hagström. A., Larsson, U. (1984). Diel and seasonal variation in growth rates of pelagic bacteria. In: Hobbie, J. E., Willıams, P. J. (eds.) Heterotrophic activity in the sea. Plenum Press, New York, p. 249-262

Harris, G. P. (1986). Phytoplankton ecology: structure, function and fluctuation. Chapman and Hall, New York

Iturnaga, R., Marra, J. (1988). Temporal and spatial variability of chroococcoid cyanobacteria Synechococcus spp. Specific growth rates and their contribution to primary production in the Sargasso Sea. Mar. Ecol. Prog. Ser 44: 175-181

Jensen, A., Rystad, B., Skoglund, L. (1972). The use of dialysis culture in phytoplankton studies. J. exp. mar. Biol. Ecol. 8: $241-248$

Joint, I. R., Owens, N. P. J., Pomroy, A. J. (1986). The seasonal production of picoplankton and nanoplankton in the Celtic Sea. Mar. Ecol. Prog. Ser. 28: 251-258

Kana, T M., Glibert, P. M. (1987). Effect of irradiance up to $2000 \mu \mathrm{E} \mathrm{m}^{-2} \mathrm{~s}^{-1}$ on marine Synechococcus WH 7803 - I. Growth, pigmentation and cell composition. J. Plankton Res. 9: 79-90

Kilham, S. S., Kilham, P. (1982). The importance of resource supply rates in determining phytoplankton community structure. In: Meyers, D. G., Strickler, J R. (eds.) Trophic dynamics of aquatic ecosystems. AAAS Selected Symposium 85. American Association for the Advancement of Science, Washington, DC, p. 7-27

Kirk, T K. (1980). Studies on the physiology of lignın metabolism by white-rot fungi. In: Kirk, T., Chang, H. (eds.) Lignin biodegradetion: microbiology, chemistry and potential application. CRC Press, Boca Raton, p. 51- 64

Landry, M. R., Hass, L. W., Fagerness, V. L. (1984). Dynamics of microbial plankton communities: experiments in Kaneohe Bay, Hawaii. Mar. Ecol. Prog. Ser. 16: 127-133

Letarte, Y., Pinel-Alloul, B. (1991). Relationships between bacterioplankton production and limnological variables: necessity of bacterial size considerations. Limnol. Oceanogr. 36: 1208-1216

Li, W. K., Wood, A. M. (1988). Vertical distribution of North Atlantic ultraphytoplankton: analysis by flow cytometry and epifluorescence microscopy. Deep Sea Res. 35: 1615-1638

Lins Da Silva, N. M. (1991). Etude de la répartition spatiotemporelle des peuplements microbiens planctoniques en Mer Ligure (Méditerranée Nord-Occidentale). Ph.D. thesis, Univ. P. and M. Curie, Paris VI

Moll, R., Brahce, M. (1986). Seasonal and spatial distribution of bacteria, chlorophyll and nutrients in nearshore Lake Michigan. J. Great Lakes Res. 12: 52-62

Morris, I., Glover, H. (1981). Physiology and photosynthesis by marine coccoid cyanobacteria. Some ecological implications. Limnol. Oceanog. 11: 307-311

Platt, T., Subba-Rao, D. V., Irwin, B. (1983). Photosynthesis of picoplankton in the oligotrophic ocean. Nature 300: 702-704

Porter, K., Feig, Y. S. (1980). The use of DAPI for identifying and counting aquatic microflora. Limnol. Oceanogr. 25: 943-948

Rassoulzadegan, F. (1979). Cycles annuels de la distribution des différentes catégories de particules de seston et essai d'identification des principales poussées phytoplanctoniques dans les eaux néritiques de Villefranche-sur-mer. J. exp. mar. Biol. Ecol. 38: 41-56 
Rassoulzadegan, F. (1993). Protozoan patterns in the Azam-Ammerman's bacteria-phytoplankton mutualism. In: Gurrero, R., Pedros-Alió, C. (eds.) Trends in microbial ecology. Spanish Society for Microbiology, Barcelona, p. $435-439$

Ray, R. T., Haas, L. W.. Sieracki, M. E. (1989). Autotrophic picoplankton dynamics in a Chesapeake Bay sub-estuary. Mar. Ecol. Prog. Ser. 52: 273-285

Rothhaupt, K. O. (1992). Stimulation of phosphorus-limited phytoplankton by bactivorous flagellates in laboratory experiments. Limnol. Oceanogr 37.750-759

Scavia, D., Laird, G. A. (1987). Bacterioplankton in Lake Michigan: dynamics, controls and significance to carbon flux. Limnol. Oceanogr. 32: 1017-1033

Selmer, J. S., Ferrier-Pages, C., Cellario, C., Rassoulzadegan, F. (1993). New and regenerated production in relation to the microbial loop in the NW Mediterranean Sea. Mar. Ecol. Prog. Ser. 100: 71-83

Sheldon, R. W., Rassoulzadegan, F. (1987). A method for measuring plankton production by particle counting. Mar. Microb. Food Webs 2: 29-44

Shortreed, K. S., Stockner, J. G. (1986). Trophic status of 19 subartic lakes in the Yukon Territory. Can. J. Fish. Aquat. Sci. 43: 787-805

Sommer, U., Gliwicz, M., Lampert, W., Duncan, A. (1986). The

This article was submitted to the editor
PEG-model of seasonal succession of planktonic events in fresh waters. Arch. Hydrobiol. 106: 433-471

Stoeckner, J. G., Antia, N. J (1986). Algal picoplankton from marine and freshwater ecosystems: a multidiciplinary perspective. Can. J. Fish. Aquat. Sci. 43: 2472-2503

Taylor, G. T., Iturriaga, R., Sullivan, C. W. (1985). Interactions of bactivorous grazers and heterotrophic bacteria with dissolved organic matter. Mar. Ecol. Prog. Ser. 22: 129-141

Takahashi, M., Bienfang, P. K. (1983). Size structure of phytoplankton biomass and photosynthesis in subtropical Hawaiian waters. Mar. Biol. 76: 203-211

Throndsen. J (1976). Occurrence and productivity of small marine flagellates. Norw. J. Bot. 23: 269-293

Treguer, P., Le Corre, P. (1975). Manuel d'analyse des sels nutritifs dans l'eau de mer (utilisation de l'Autoanalyseur II Technicon), 2è ed. Lab. d'Océanographie., Chim. Univ. Bretagne Occidentale, Brest, p. 1-110

Utermöhl, H. (1958). Zur Vervollkommnung der quantitativen Phytoplankton Methodik. Comm. Ass. int. Limnol. theor. appl. 9: 1-38

Waterbury, J. B., Watson, S. W., Valois, F. W., Franks, D. G. (1986). Biological and ecological characterization of the marine unicellular cyanobacterium Synechococcus. In: Platt, T., Li, W. K. W. (eds.) Photosynthetic picoplankton. Can. Bull. Fish. Aquat. Sci. 214: 74-120

Manuscript first received: September 27, 1993

Revised version accepted: March 28, 1994 